IWONA LUPA-WósCIK

Pedagogical University of Krakow, Poland

\title{
The Role of Social Media in Entrepreneurship: a Conceptual Case Study
}

\begin{abstract}
The growing importance of social media in entrepreneurship has been observed for a long time already. Their impact is multidimensional and applies to all sectors: private, public and non-governmental. This article focuses on selected entrepreneurship aspects, and it aims to determine the role of social media in entrepreneurship based on selected issues with particular reference to the functioning of enterprises and influencing consumer behaviour. The author has considered the impact of social media on businesses and consumer behaviour. It was determined how social media enable enterprises to interact with consumers and affect demand and supply, including the phenomenon of prosumption. Thus, it can be assumed that social media influence economic equilibrium. Besides, social media allow the optimisation of operating costs and enable more efficient use of resources. They also have a real impact on consumer decisions. As a research method, an in-depth analysis of secondary data available in the literature was used. The article includes theoretical discussion supported by the research of other writers in the literature relating to the issue analysed. The analysis has shown the significant role of social media in the business entrepreneurship economy.
\end{abstract}

Keywords: consumer decisions; economy; entrepreneurship; social media

Received: 28 November 2019

Accepted: 19 October 2020

\section{Suggested citation:}

Lupa-Wójcik, I. (2020). The Role of Social Media in Entrepreneurship: a Conceptual Case Study. Przedsiębiorczość - Edukacja [Entrepreneurship - Education], 16(2), 176-188. doi: $10.24917 / 20833296.162 .14$

\section{Introduction}

Social media are a place of interaction between all entities of entrepreneurship. This leads them to have enormous economic potential, often underestimated and unused. Meanwhile, the impact of these media on entrepreneurship is complex and multidimensional, especially concerning business and consumer sectors. 
The purpose of this article is to determine the role of social media in entrepreneurship on selected issues with particular reference to the functioning of enterprises and influencing consumer behaviour. As a research method, an in-depth analysis of secondary data available in the literature was used.

The article consists of four parts. The first discusses issues related to the economic potential of social media and presents a model of economic relations between various economic entities. The second part presents the economic aspects related to the use of social media in business operations, followed by the economic importance of prosumption. The last part describes the impact of social media on consumer behaviour.

\section{The economic potential of social media}

In the subject literature, social media are defined as a category of social technologies which use the internet and mobile media (movies, documents, photos, multimedia presentations, etc.) to share ideas and messages, and for entertainment (Klososky, 2011). These are collections of websites and applications that ensure users interact with people they know (Brown, 2012). Generally, it can be assumed that social media are online platforms (websites or applications) whose functions are primarily to create, process, play, share, and receive visual and audio content (e.g. text, images, movies, games) (Heymann-Reder, 2011) by various entities (individual and/or institutional) and respond to them in various forms. They can be open (available to all users of the internet) or closed (available to a specific group of users, e.g. employees of a specific corporation (like Yammer) or scientists (like ResearchGate).

Social media are gaining popularity around the world. As of January 2020, 3.8 billion people had active social media accounts, representing $49 \%$ of the world's population. Compared to the same period in the previous year, this number had increased by 321 million (9.2\% increase). In Poland, $50 \%$ of the population has active social media accounts (19 million), an increase of $7.8 \%$ over the same period a year earlier. The most active social media platforms in Poland include YouTube (92\%), Facebook (89\%) and Messenger (72\%), while Instagram (55\%), WhatsApp (45\%) and Twitter (35\%) are also popular (Heymann-Reder, 2011). All presented statistics testify to the very high economic potential of social media, manifested in the fact that various entities, both private and public, and various types of organisations and individuals operate in these media. Initially, social media were a platform for interaction between users who were individuals. However, their dynamic development has meant that other entities (including financial institutions, non-profit organisations, government organisations, enterprises) began to see many benefits that allow organisation goals to be achieved. Therefore, social media are a place of mutual interaction between all economic entities (Figure 1). It is also worth noting that there are no geographical barriers, and thus they may be a meeting place with foreign entities.

Table 1 presents a model of economic relations on social media between various economic entities.

On social media, there are very complex interactions between various types of economic entities that have a real economic dimension. It should be noted that social media are not only used for communication between users or promotional activities of various 
Table 1. Model of economic relations on social media between various economic entities

\begin{tabular}{|c|c|c|c|}
\hline & $\begin{array}{l}\text { Business } \\
\text { (B) }\end{array}$ & $\begin{array}{l}\text { Consumers } \\
\text { (C) }\end{array}$ & Financial institutions (F) \\
\hline 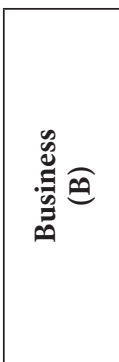 & $\begin{array}{l}\text { B/B: } \\
\text { B2B leads acquisition } \\
\text { Sale of goods and services } \\
\text { Social selling B2B } \\
\text { Maintaining relationships } \\
\text { Information (promotion) } \\
\text { Building a relationship } \\
\text { Knowledge exchange } \\
\text { Monitoring of competition }\end{array}$ & $\begin{array}{l}\text { C/B: } \\
\text { Familiarising with } \\
\text { offer } \\
\text { Purchase of goods and } \\
\text { services } \\
\text { Prosumption } \\
\text { Monitoring } \\
\text { Reporting problems, } \\
\text { complaints, new initiatives } \\
\text { Recommendations, reviews }\end{array}$ & $\begin{array}{l}\text { F/B: } \\
\text { Information about } \\
\text { offer } \\
\text { Sale of financial services } \\
\text { Maintaining relationships } \\
\text { Building trust }\end{array}$ \\
\hline 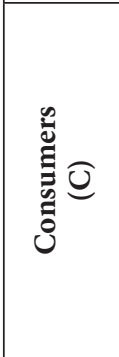 & $\begin{array}{l}\text { B/C: } \\
\text { Information (promotion) } \\
\text { Build interest } \\
\text { Lead acquisition } \\
\text { Sale of goods and services } \\
\text { Employer branding } \\
\text { Recruitment of employees } \\
\text { Employee control }\end{array}$ & $\begin{array}{l}\text { C/C: } \\
\text { Networking } \\
\text { Recommendations } \\
\text { Building a relationship } \\
\text { Exchange of resources } \\
\text { Social sharing } \\
\text { Exchange of information } \\
\text { and knowledge } \\
\text { Social saving, Social lending } \\
\text { Crowdfunding }\end{array}$ & $\begin{array}{l}\text { F/C: } \\
\text { Information about offer } \\
\text { Sale of financial services } \\
\text { Maintaining relationships } \\
\text { Building trust }\end{array}$ \\
\hline 䄈泀 & \begin{tabular}{|l|} 
B/F: \\
Familiarising with offer \\
Purchase of financial \\
services \\
Making financial \\
transactions \\
Monitoring the situation on \\
the financial market
\end{tabular} & $\begin{array}{l}\text { C/F: } \\
\text { Familiarising with offer } \\
\text { Purchase of financial } \\
\text { services } \\
\text { Making financial } \\
\text { transactions } \\
\text { Monitoring the situation on } \\
\text { the financial market }\end{array}$ & $\begin{array}{l}\text { F/F: } \\
\text { Building a relationship } \\
\text { Sale of financial services } \\
\text { Maintaining relationships } \\
\text { Notifications } \\
\text { Knowledge exchange } \\
\text { Cooperation }\end{array}$ \\
\hline 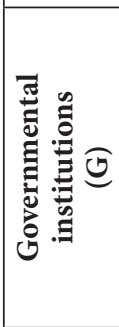 & $\begin{array}{l}\text { B/G: } \\
\text { Building a relationship } \\
\text { Sale of goods and services } \\
\text { Situation monitoring } \\
\text { Update of information } \\
\text { on the political and legal } \\
\text { market } \\
\text { Reporting any other } \\
\text { business }\end{array}$ & $\begin{array}{l}\text { C/G: } \\
\text { Submission of social and } \\
\text { civic initiatives } \\
\text { Situation monitoring } \\
\text { Update of information } \\
\text { on the political and legal } \\
\text { market }\end{array}$ & $\begin{array}{l}\text { F/G: } \\
\text { Building a relationship } \\
\text { Sale of financial services } \\
\text { Monitoring of the situation, } \\
\text { updating information } \\
\text { on the political and legal } \\
\text { market } \\
\text { Building trust }\end{array}$ \\
\hline 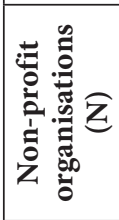 & $\begin{array}{l}\mathrm{B} / \mathrm{N}: \\
\text { Image building } \\
\text { Building a relationship } \\
\text { Knowledge exchange } \\
\text { Cooperation }\end{array}$ & $\begin{array}{l}\mathrm{C} / \mathrm{N}: \\
\text { Engaging in social } \\
\text { initiatives } \\
\text { social work } \\
\text { Knowledge exchange } \\
\text { Gaining new contacts } \\
\end{array}$ & $\begin{array}{l}\text { F/N: } \\
\text { Building trust } \\
\text { Building a relationship } \\
\text { Knowledge exchange } \\
\text { Cooperation }\end{array}$ \\
\hline 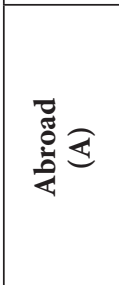 & $\begin{array}{l}\text { B/A: } \\
\text { Leads acquisition } \\
\text { Building and maintaining } \\
\text { relationships } \\
\text { Sale } \\
\text { Knowledge exchange } \\
\text { Cooperation } \\
\text { Export and import support }\end{array}$ & $\begin{array}{l}\text { C/A: } \\
\text { Networking } \\
\text { Building a relationship } \\
\text { Exchange of information } \\
\text { and knowledge }\end{array}$ & $\begin{array}{l}\text { F/A: } \\
\text { Lead acquisition } \\
\text { Building and maintaining } \\
\text { relationships } \\
\text { Sale } \\
\text { Knowledge exchange } \\
\text { Cooperation }\end{array}$ \\
\hline
\end{tabular}

Source: author 


\begin{tabular}{|c|c|c|c|}
\hline & \begin{tabular}{|c|} 
Governmental institutions \\
$(\mathrm{G})$
\end{tabular} & $\begin{array}{l}\text { Non-profit organizations } \\
(\mathrm{N})\end{array}$ & $\begin{array}{l}\text { Abroad } \\
\text { (A) }\end{array}$ \\
\hline 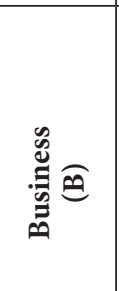 & $\begin{array}{l}\text { G/B: } \\
\text { Investigation } \\
\text { Monitoring the situation } \\
\text { Notifications } \\
\text { Knowledge exchange }\end{array}$ & $\begin{array}{l}\text { N/B: } \\
\text { Gaining donors } \\
\text { Gaining volunteers } \\
\text { Gaining sponsors for } \\
\text { various initiatives } \\
\text { Cooperation } \\
\text { Knowledge exchange }\end{array}$ & \begin{tabular}{|l} 
A/B: \\
Lead acquisition \\
Building and maintaining \\
relationships \\
Sale \\
Knowledge exchange \\
Cooperation \\
Export and import support
\end{tabular} \\
\hline 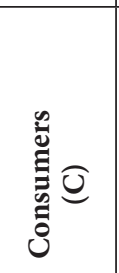 & $\begin{array}{l}\text { G/C: } \\
\text { Household control } \\
\text { Monitoring the situation of } \\
\text { households } \\
\text { Notifications } \\
\text { Knowledge exchange }\end{array}$ & $\begin{array}{l}\text { N/C: } \\
\text { Crowdfunding } \\
\text { Gaining volunteers } \\
\text { Cooperation } \\
\text { Knowledge exchange }\end{array}$ & $\begin{array}{l}\text { A/C: } \\
\text { Networking } \\
\text { Building a relationship } \\
\text { Exchange of information } \\
\text { and knowledge }\end{array}$ \\
\hline 诖 & $\begin{array}{l}\text { G/F: } \\
\text { Control of financial } \\
\text { institutions } \\
\text { Monitoring the situation of } \\
\text { these institutions } \\
\text { Notifications } \\
\text { Knowledge exchange }\end{array}$ & $\begin{array}{l}\text { N/F: } \\
\text { Gaining donors } \\
\text { Gaining sponsors for } \\
\text { various initiatives } \\
\text { Cooperation } \\
\text { Knowledge exchange }\end{array}$ & $\begin{array}{l}\text { A/F: } \\
\text { Lead acquisition } \\
\text { Building and maintaining } \\
\text { relationships } \\
\text { Sale } \\
\text { Knowledge exchange } \\
\text { Cooperation }\end{array}$ \\
\hline 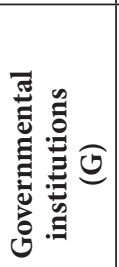 & $\begin{array}{l}\text { G/G: } \\
\text { Building a relationship } \\
\text { Cooperation } \\
\text { Exchange of information } \\
\text { and knowledge } \\
\text { Institution control } \\
\text { Situation monitoring }\end{array}$ & $\begin{array}{l}\text { N/G: } \\
\text { Gaining donors } \\
\text { Gaining sponsors for } \\
\text { various initiatives } \\
\text { Cooperation } \\
\text { Knowledge exchange }\end{array}$ & $\begin{array}{l}\text { A/G: } \\
\text { Building a relationship } \\
\text { Cooperation } \\
\text { Exchange of information } \\
\text { and knowledge }\end{array}$ \\
\hline 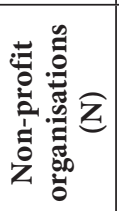 & $\begin{array}{l}\text { G/N: } \\
\text { Building a relationship } \\
\text { Knowledge exchange } \\
\text { Cooperation } \\
\text { Founding }\end{array}$ & $\begin{array}{l}\text { N/N: } \\
\text { Cooperation } \\
\text { Knowledge exchange } \\
\text { Volunteer exchange } \\
\text { Building a relationship }\end{array}$ & $\begin{array}{l}\text { A/N: } \\
\text { Cooperation } \\
\text { Knowledge exchange } \\
\text { Building a relationship }\end{array}$ \\
\hline 吾要 & $\begin{array}{l}\text { G/A: } \\
\text { Building a relationship } \\
\text { Cooperation } \\
\text { Exchange of information } \\
\text { and knowledge } \\
\text { Situation monitoring }\end{array}$ & $\begin{array}{l}\text { N/A: } \\
\text { Gaining donors } \\
\text { Gaining sponsors for } \\
\text { various initiatives } \\
\text { Cooperation } \\
\text { Knowledge exchange }\end{array}$ & $\begin{array}{l}\text { A/A: } \\
\text { Building a relationship } \\
\text { Cooperation } \\
\text { Exchange of information } \\
\text { and knowledge } \\
\text { Situation monitoring }\end{array}$ \\
\hline
\end{tabular}


organisations as financial transactions occur on these platforms as well. It is possible to sell or make payments (Pritchard, 2019). In the G/B and G/C relation, it is worth paying attention to the methods used to control business and consumers through social media by government institutions. For example, there are practices in Poland when the Social Insurance Institution checks via Facebook whether a person who is receiving social sickness benefit is actually sick and does not, for example, stay away from home on vacation (Szewioła, 2019). Such practices have an economic dimension on a macro scale because they make citizens less likely to abuse social benefits. Similarly, social media are increasingly becoming a place for public debate and reporting various types of social and civic initiatives that are being implemented. Social problems are also reported and, at the same time, possibilities for solving them are presented.

It should be emphasised that the model presented in Table 1 is not a closed catalogue. It is possible to continually expand it by joining various types of organisations and/or pointing to other possible relationships. Undoubtedly, each relation presented in Table 1 requires a detailed economic analysis, after which it will be possible to present their real economic potential. In this article, attention is primarily focused on selected microeconomic issues: business - consumers $(\mathrm{B} / \mathrm{C})$ and consumers - business $(\mathrm{C} / \mathrm{B})$ relation.

Figure 1. Model of interaction between various entities on social media

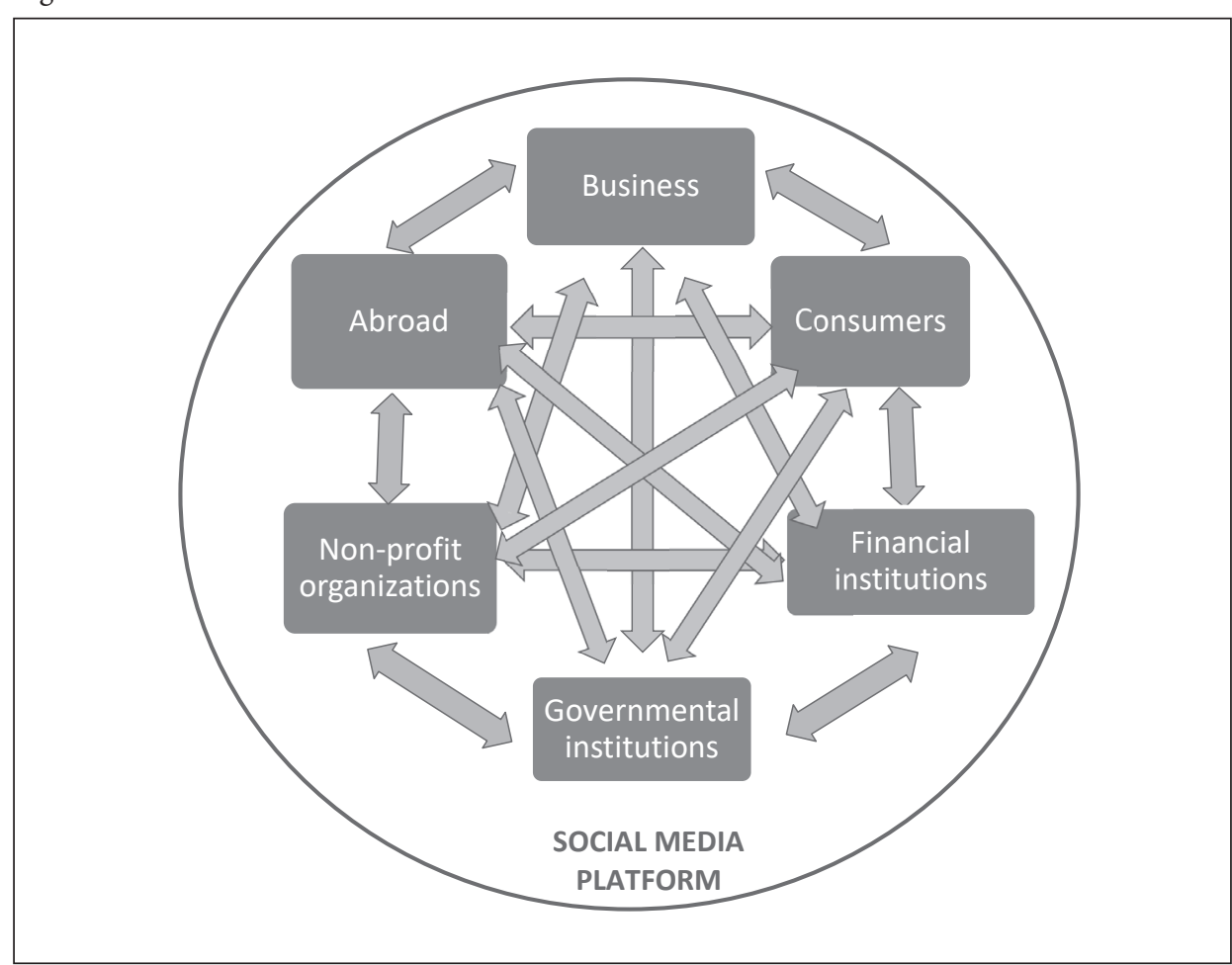

Source: author 


\section{Economic aspects associated with the use of social media in business activities}

Companies in their activities currently use social media on a large-scale (Aral, Dellarocas, Godes, 2013; Safko, 2010). The following factors determined this:

- concentration of a large number of users (potential or current clients, partners, contractors, employees, etc.),

- discussion by users regarding company products and their activities, which require social media monitoring,

- possibility of user segmentation due to various criteria (e.g. geographic, demographic, etc.),

- possibility of using various forms of marketing,

- development of tools supporting business on social media (advertising tools, monitoring tools, etc.).

These and others decide that social media have great potential for business operations, mainly marketing. They have revolutionised the activities of many economic entities in the world, regardless of their size or scale of activity. These media provide the opportunity to communicate on any scale, in a relatively short time and with relatively little effort (Mangold, Faulds, 2009). They provide a quick and direct exchange of all content regardless of the geographical distance of users. Through them, information can be created, shared and sent, which has elementary importance in the age of modern economy.

Social media are increasingly becoming the main channel for maintaining relationships with consumers. Some companies have given up telephone contact for e-mail or social network websites. The growing popularity of social media has meant that they are increasingly used by companies to promote products and brands allowing a group of loyal consumers to be created while successfully gaining new ones (PARP, 2018).

Caring for the best consumer relationship has great economic importance. According to research conducted on Polish companies from the small and medium-sized business sector, the main reasons for the loss of financial liquidity in 2018 include the loss of consumers (42\%). Companies are afraid of deterioration in consumer relationships and, therefore, in their strategies, they mainly focus on consumer service as the most effective way of generating added value (PARP, 2018). This is highly rational, given the fact that getting a new consumer is six to seven times more expensive than keeping an existing one. Moreover, the probability of selling to existing consumers is fourteen times higher than the probability of selling to a new one. It should also be added that $73 \%$ of satisfied consumers will recommend the company to others, and $46 \%$ will also trust other products and services of a given company more than the products of competitors (Jóźwiak, 2017). When considering all this data, the economic importance of building and maintaining relationships with clients should be emphasised. In the Stelzner (2019) report the surveyed companies indicated the following as the main benefits of social media marketing: generated leads (74\%), improved sales (72\%), developed loyal fans (71\%), as well as growing business partnerships (56\%). These results demonstrate that social media can generate considerable economic benefits, partly based on the possibility of building long-term relationships with consumers.

For business, social media have become a relatively inexpensive and effective marketing channel. According to research conducted on 689 companies in April 2017, social media are rated as a "good" (34\%) or "medium" (33\%) marketing channel, taking into 
account ROI (Return on Investment) while the relatively low promotion costs in these media represent a real economic benefit for business (Email Marketing..., 2017).

The main cost associated with promotion on social media is expenditure on advertising. In Poland, the share of expenditure on advertising on social media in all online advertising was $16.7 \%$ in 2018 , an increase of $22 \%$ compared to the previous year. The social media advertising industry is growing exceptionally dynamically, one of the fastest-growing sectors of online advertising (IAB Polska, 2018). According to the M.A. Stelzner (2019) report, marketing specialists regularly use the Facebook platform (72\%) as well as Instagram (38\%) for social media advertisements (Stelzner, 2019). Facebook is the world's second primary global digital advertising seller. As of February 2019, its net digital advertising revenue was USD 67.37 billion. Only Google was ahead of Facebook (USD 103.73 billion) (Emarketer, 2019).

The effectiveness of advertising on Facebook (as well as on other social media), understood as the ratio of the profit from an advertisement to the expenditure incurred on it, depends on many factors including industry, type of product, type of consumer, type of advertisement, its creation, etc. (Lupa, 2017). Table 2 presents examples of the effects of an advertising campaign for selected companies on Facebook.

Table 2. The effects of advertising campaigns on Facebook based on selected companies

\begin{tabular}{|c|c|c|}
\hline $\begin{array}{l}\text { Company } \\
\text { (industry) }\end{array}$ & $\begin{array}{c}\text { The goal of } \\
\text { an advertising } \\
\text { campaign } \\
\text { on Facebook }\end{array}$ & $\begin{array}{c}\text { The effects of an advertising campaign } \\
\text { on Facebook }\end{array}$ \\
\hline $\begin{array}{l}\text { Modbis (women's } \\
\text { clothing) }\end{array}$ & $\begin{array}{l}\text { Conversion rate } \\
\text { increase }\end{array}$ & $\begin{array}{l}\text { - 22x return on advertising expenditure } \\
- \text { Sales increase by } 29 \% \\
-27 \% \text { increase in conversion rate }\end{array}$ \\
\hline $\begin{array}{l}\text { Meliá Hotels } \\
\text { International } \\
\text { (hospitality } \\
\text { industry) }\end{array}$ & $\begin{array}{l}\text { Presenting selected } \\
\text { groups of hotels to } \\
\text { potential clients }\end{array}$ & $\begin{array}{l}-6 \text { to } 7 \mathrm{x} \text { return on advertising expenses } \\
- \text { a } 79 \% \text { drop in the overall cost of one booking }\end{array}$ \\
\hline $\begin{array}{l}\text { Tostitos (producer } \\
\text { of tortilla chips, dips } \\
\text { and salsa sauces } \\
\text { with many flavours) }\end{array}$ & $\begin{array}{l}\text { Increasing } \\
\text { recognition and } \\
\text { sales of the limited } \\
\text { version of the Lucky } \\
\text { Bag, prepared for } \\
\text { the occasion of the } \\
\text { NFL league finals }\end{array}$ & $\begin{array}{l}\text { - } 1.7 \% \text { increase in sales } \\
-0.9 \% \text { increase in popularity in households } \\
-9 \text { point increase in brand favour } \\
-1.6 \mathrm{x} \text { return on advertising expenditure, } \\
-22 \% \text { higher reach due to advertising material } \\
\text { rules compared to standard segmentation } \\
-37.8 \text { million ad recipients }\end{array}$ \\
\hline $\begin{array}{l}\text { MuteSix (digital } \\
\text { marketing agency) }\end{array}$ & $\begin{array}{l}\text { Increase sales } \\
\text { and return on } \\
\text { investment in } \\
\text { advertising }\end{array}$ & $\begin{array}{l}-4 \mathrm{x} \text { increase in revenue for the JibJab brand } \\
-33 \% \text { decrease in the cost of one action (purchase) } \\
\text { for the JibJab brand } \\
-\quad 7 \mathrm{x} \text { increase in revenues (over USD } 1 \text { million) for } \\
\text { the BauBax } 2 \text { brand } \\
-21 \% \text { decrease in the cost of one action (purchase) } \\
\text { for the BauBax } 2 \text { brand } \\
-\quad 4.21 \mathrm{x} \text { return on advertising expenses for the Mott } \\
\text { \& Bow brand } \\
- \text { a } 27 \% \text { decrease in the cost of one action } \\
\text { (purchase) for the Mott \& Bow brand }\end{array}$ \\
\hline
\end{tabular}




\begin{tabular}{|c|c|c|}
\hline $\begin{array}{l}\text { Company } \\
\text { (industry) }\end{array}$ & $\begin{array}{l}\text { The goal of } \\
\text { an advertising } \\
\text { campaign } \\
\text { on Facebook }\end{array}$ & $\begin{array}{c}\text { The effects of an advertising campaign } \\
\text { on Facebook }\end{array}$ \\
\hline $\begin{array}{l}\text { Molecules (producer } \\
\text { of air purification } \\
\text { technology) }\end{array}$ & $\begin{array}{l}\text { Increasing sales } \\
\text { among new } \\
\text { consumers; } \\
\text { optimisation of the } \\
\text { advertising budget }\end{array}$ & $\begin{array}{l}\text { - as a result of optimisation, the cost of buying } \\
\text { Facebook ads is } 19 \% \text { lower } \\
-1.25 x \text { higher return on advertising }\end{array}$ \\
\hline $\begin{array}{l}\text { Free Fly Apparel } \\
\text { (bamboo clothing } \\
\text { brand) }\end{array}$ & $\begin{array}{l}\text { Increasing the } \\
\text { number of } \\
\text { purchases on the } \\
\text { website; budget } \\
\text { optimisation }\end{array}$ & $\begin{array}{l}\text { - } 11 \% \text { higher return on advertising expenditure } \\
\text { compared to the previous Facebook strategy } \\
-50 \% \text { increase in the number of purchases } \\
\text { compared to the previous Facebook strategy } \\
- \text { a } 50 \% \text { increase in revenues compared to the } \\
\text { previous Facebook strategy }\end{array}$ \\
\hline $\begin{array}{l}\text { Bella Bridal } \\
\text { Boutique (boutique } \\
\text { with wedding } \\
\text { accessories) } \\
\end{array}$ & $\begin{array}{l}\text { Recruitment of } \\
\text { wedding consultants }\end{array}$ & $\begin{array}{l}\text { - obtaining } 60 \text { candidates as a result of job offers } \\
\text { on Facebook } \\
-3 \text { employees employed as a result of Facebook } \\
\text { job offers }\end{array}$ \\
\hline $\begin{array}{l}\text { Bake'n Babes } \\
\text { (bakery) }\end{array}$ & \begin{tabular}{|l|} 
Recruitment of \\
bakery employees
\end{tabular} & $\begin{array}{l}\text { - } 7 \text { days (on average) from the publication } \\
\text { of a post with a job offer to employment } \\
-18 \text { applications (on average) within } 48 \text { hours } \\
\text { of publication of the job offer } \\
-8 \text { out of } 9 \text { team members employed via Facebook } \\
\text { remain with the company }\end{array}$ \\
\hline
\end{tabular}

Source: author - based on Facebook 2019

The case studies presented in Table 2 show that properly conducted advertising campaigns on Facebook can be very effective and efficient. It is also worth noting that the Facebook ad tool allows budgets to be optimised so the cost of a campaign can be reduced thus increasing its efficiency (see, e.g. Molecules or Free Fly Apparel case studies). Increasingly, social media are also used to recruit employees, and the examples of Bella Bridal Boutique and Bake'n Babes show that they can be very effective.

Economic benefits for business may also result from the use of social media to improve communication within the company thanks to which it is possible the exchange of employee opinions and ideas (PARP, 2018: 65-66). Also, social media can enable the exchange of information, knowledge, documents and tasks in real time. An example is Brand24 - a Polish company operating in the IT industry. Most Brand24 employee meetings are organised in this way, as many employees work remotely (and now - during a pandemic - this applies to all employees). Therefore, the company uses many online tools in the form of social platforms to manage internal communications. For this purpose, messengers such as Skype or Google Hangouts are used. They enable videoconferences to be conducted in real time, as well as sending messages in the form of text, graphics, as files, etc. The organisation of online meetings is also greatly facilitated by ClickMeeting and Zoom which allow, for example, files with a presentation to be uploaded and a screen shared with other recipients, inviting them to participate in a webinar or generating a survey thanks to which feedback about the meeting can be received. Another tool used for similar purposes at Brand24 is Slack, an internet communication platform (internet communicator), enabling both voice and text communication with the option of 
sending files in the form of photos, video, documents, etc. The platform is distinguished by the fact that it is possible to create channels dedicated to individual company departments, teams, projects, etc. which can be public (available to every employee) or private. In addition, Brand 24 uses the Trello platform for planning, forwarding notes, tasks and work organisation in general. It is an online board to which any category in the form of lists with cards can be pinned and shared privately with selected individuals, employee teams, or with all employees. They can be adapted to individual projects and tasks while all changes are carried out in real time, with interested employees receiving relevant notifications. Trello also allows employees to send comments, as well as files and lists, tasks, labels, appointments, etc., can be added. (Lupa-Wójcik, 2019).

The use of these social media tools in Brand24 significantly improves communication within the company and enables employees to work remotely. It is of particular importance in the era of the coronavirus pandemic, as without social media, many companies would go out of business. It also highlights the growing role of these media in the economy.

\section{The economic importance of prosumption}

Innovations are of critical economic importance and determine economic development. Research shows that the main reasons for not innovating in companies in Poland include the lack of good ideas for innovation and low demand for it on the market (PARP, 2018: 48). Both problems (lack of ideas and low demand) can be tackled by using social media and the idea of the prosumer.

Many publications discuss the problem of prosumption (Beer, Burrows, 2010; Fuchs, 2014; Fuchs, 2011; Humphreys, Grayson, 2008) which arose from the combination of two terms: "production" and "consumption". The $20^{\text {th }}$-century futurist Alvin Toffler introduced this concept to the literature connecting the rise of modern technologies (including internet communication technologies) with changes in post-industrial societies in the late 1950s (Toffler, A., Toffler, H. 2006). He indicated a new type of consumer-prosumer who, using modern technologies, satisfies their own needs (Tapscott, Williams, 2006) and therefore changing their role. The prosumer not only consumes goods and services, but also actively participates in the production process, or even independently produces goods/services (so-called household self-supply), replacing the functions of the business in this area (Witczak, 2016).

In the era of social media, production and consumption processes interpenetrate each other. As a consequence, there is still a discussion in the literature about the validity of their separation (Ritzer, Jurgenson, 2010). Companies monitor social media, analyse the consumer needs reported in them and adapt products and services on this basis. Consumers are increasingly taking over tasks that initially belonged to business employees and have become active participants in production and sales processes (Witczak, 2016). First, they help in planning a product or service, e.g. they determine the shape, colour, size etc., subsequently, thanks to arranging presales, for example, it is possible to estimate demand, and thus to plan the supply volume. Then consumers make their purchases via online payment transactions. At a later stage, they assess the product in terms of whether it meets their expectations. They share these ratings with others through social media. This, in turn, continues to affect demand and supply, as will be discussed below. 
Prosumption becomes economically advantageous because it leads to a win-win situation where everyone can potentially win, including consumers. After all, they get a product that meets their expectations. Research shows that consumers value more personalised and "designed" products than unified ones on the mass market (Hildebrand et al., 2013). Companies also win because by communicating on social media, they encourage consumers to share ideas that they can later use in the creation or development of products and services. Therefore, they obtain new ideas for innovation, thanks to which they secure the right demand, and over time build a competitive advantage (Nawrocka, Niezgoda, 2017: 128-129).

\section{Impact of social media on consumer behavior}

The previous considerations have proved the economic importance of building consumer confidence. According to research (Unlocking the power..., 2019), the critical factors in building consumer confidence include consistent product quality, accurate product claims and favourable reviews. These three conditions will undoubtedly be met if companies apply the concept of the prosumer in practice. However, this has a much deeper meaning. The opinions of consumers on social media influence the shaping of attitudes and views of other consumers (Forbes, 2013; Godey et al. 2016; Stephen, 2016). Research shows that almost 9 out of 10 users follow content about brands on social media, although every third user does it only sporadically or searches for it when they intend to buy a product or service. Every fourth user (26\%) follows brands on the internet. This activity has a significant impact on the decision to buy the product/service of a given brand (80\%) and on individual opinions about a brand (76\%) (Lubię to czy kupuję to?..., 2016). Among more than half of internet users, brand tracking also affects recommendations to other users and the willingness to express opinions about it. The content tracked has a significant impact on the decision to buy a product or service for a given brand (as many as $80 \%$ of respondents who track information about brands online). Eight out of ten say that content left on the internet by other users has an impact on their brand perception. Importantly, if an internet user plans to buy a product or service for a given brand, and reads negative opinions about it on social media, $41 \%$ of respondents would give up their purchase (Lubię to czy kupuję to?..., 2016).

Negative opinions do not have to prejudge a company's failing position; it can always be fixed. If the company apologises or promises to improve the situation, only $28 \%$ would give up purchasing. This shows that companies are not helpless in the face of the dominant position of consumers on social media. Appropriate intervention can save the company's image and stop the spiral of negative opinion, at the same time, avoiding real financial losses. On the other hand, the lack of reaction from a company may cause an avalanche of negative comments, which could spiral, leading to a social media crisis. This can be defined as a situation in which the image of the company is suddenly and rapidly threatened as a result of the dissemination of negative opinions about it on social media. Such a situation, however, brings not only negative image-related effects but also economic ones, not only a decrease in sales but also alternative costs (how much would the company have earned if the crisis had not occurred? How many new consumers would it have gained if this had not happened?), as well as compensation costs. For example, in Poland in August 2017, the Tiger (a popular energy drink brand) crisis began on social 
media. To prevent its further escalation and rectify the situation, the brand paid PLN 500,000 (about USD 125,000) to charity and also incurred many other transaction costs (e.g. it had to terminate the contract with the business responsible for its social media communication) (Międzik, 2017). Without going into detail, it should be emphasised that from an economic point of view, social media can be both an opportunity and a threat to a company. Indeed, consumers have a dominant position. However, companies are not vulnerable, and having the right strategy is vital.

\section{Conclusion}

Social media are a place of mutual interaction for all economic entities and are no longer used only for communication or marketing. On these platforms products or services can be ordered, financial transactions made and much more. Social media have great business potential and have revolutionised the activities of many companies in the world, regardless of their size or scale of activity. These media allow communicating at any scale, in a relatively short time and with relatively little effort. Social media can generate considerable economic benefits, mainly thanks to the possibility of building long-term relationships with consumers.

From a company's point of view, social media have become a relatively inexpensive and effective marketing channel, and their low promotion costs represent a real economic benefit. The examples presented of various companies showed that on social media, it is possible to optimise costs, monitor demand and adjust supply. Proper use by a company (whether it is its internal platforms created for its needs, or external, such as Facebook, etc.) allows a market equilibrium to be achieved where supply is adapted to current demand. Such activities on a larger scale can have a beneficial economic effect on the entire economy. Economic benefits for business can also result from the use of social media to improve communication within a company, the organisation of work, file and document exchange, online meetings, remote work support, etc. Such solutions result in significant savings for both the company and its employees. Physical and geographical barriers cease to matter, which means lower transaction costs, but also significantly lower alternative costs.

On the other hand, using social media in business can have some adverse effects too. The opinions of consumers left on social media influence the attitudes and views of other consumers. Low quality of products or services will most likely be reflected there, which can have a real impact on financial results. It means that, as never before, it is economically justified to care for the quality of products and services, as well as for relations with consumers.

\section{References}

Aral, S., Dellarocas, C., Godes, D. (2013). Introduction to the special issue - social media and business transformation: a framework for research. Information Systems Research, 24(1), 3-13.

Asap Care 24. (2019). Konsumenci, marki i nowa komunikacja. Raport z badania preferencji konsumenckich $w$ kanałach online. Retrived from: https://nowymarketing.pl/a/21987,asap-care-24-konsumenci-marki-i-nowa-komunikacja-raport 
Beer, D., Burrows, R. (2010). Consumption, prosumption and participatory web cultures: An introduction. Journal of Consumer Culture, 10(1). Retrieved from: https://journals.sagepub.com/doi/ pdf/10.1177/1469540509354009

Brown, E. (2012). Working the Crowd: Social Media Marketing for Business. Swindon: BCS Learning and Development.

Email Marketing Industry Census 2017. (2017). Retrieved from: https://econsultancy.com/reports/2017-email-census/

Emarketer. (2019). What's Shaping the Digital Ad Market. Retrived from: https://www.emarketer.com/ content/global-digital-ad-spending-2019

Facebook for Business. (2019). https://www.facebook.com/business/success/

Forbes, L.P. (2013). Does social media influence consumer buying behavior? An investigation of recommendations and purchases. Journal of Business \& Economics Research, 11(2), 107-112.

Fuchs, C. (2014). Digital prosumption labour on social media in the context of the capitalist regime of time. Time \& Society, 23(1), 97-123.

Fuchs, C. (2011). Web 2.0, prosumption, and surveillance. Surveillance \& Society, 8(3), 288-309.

Godey, B., Manthiou, A., Pederzoli, D., Rokka, J., Aiello, G., Donvito, R., Singh, R. (2016). Social media marketing efforts of luxury brands: Influence on brand equity and consumer behavior. Journal of Business Research, 69(12), 5833-5841.

Heymann-Reder, D. (2011). Social Media Marketing: Erfolgreiche Strategien fur Sie und Ihr Unternehmen. Munchen: Addison-Wesley Verlag.

Hamari, J., Sjöklint, M., Ukkonen, A. (2016). The sharing economy: Why people participate in collaborative consumption. Journal of the Association for Information Science and Technology, 67(9), 2047-2059.

Hildebrand, Ch., Häubl, G., Herrmann, A., Landwehr, J.R. (2013). Conformity and the Crowd. Harvard Business Review, 23. Retrived from: https://hbr.org/2013/07/conformity-and-the-crowd

Humphreys, A., Grayson, K. (2008). The intersecting roles of consumer and producer: A critical perspective on co-production, co-creation and prosumption. Sociology Compass, 2(3), 963-980.

IAB Polska. (2018). Internet 2017/2018. Raport Strategiczny. Warszawa: IAB Polska.

Jóźwiak J. (2017). 6 razy bardziej kosztowne jest zdobycie nowego klienta niż utrzymanie obecnego. Retrived from: http://consumerserviceautomation.pl/6-razy-bardziej-kosztowne-jest-zdobycie-nowego-klienta-niz-utrzymanie-obecnego/

Klososky, S. (2011). Business social technology. Texas, Austin: Greenleaf Book Group LLC.

Laurell, C., Sandström, C. (2017). The sharing economy in social media: Analysing tensions between market and non-market logics. Technological Forecasting and Social Change, 125, 58-65.

Lubię to czy kupuje to? Jak media społecznościowe wspieraja sprzedaż?. Raport Izby Gospodarki Elektronicznej. (2016). Warszawa: E-commerce.

Lupa, I. (2017). Efektywność działań marketingowych w mediach społecznościowych. Katowice: Wydawnictwo Sophia.

Lupa-Wójcik, I. (2019). Komunikacja wewnętrzna w organizacji wirtualnej na przykładzie Brand24. Zeszyty Naukowe Wyższej Szkoły Humanitas. Zarządzanie, 1, 171-186.

Łaszek, A. (2018). E-rozwój cyfrowe technologie a gospodarka, Forum Obywatelskiego Rozwoju, Warszawa.

Mangold, W.G., Faulds, D.J. (2009). Social Media: The New Hybrid Element of the Promotion Mix. Journal of Business Horizons, 52, 357-365.

Międzik, S. (2017). Kryzys tigera w social mediach - na co nie może pozwalać sobie marka?. Retrived from: https://www.ltb.pl/kryzys-tigera-w-social-mediach-na-co-nie-moze-pozwalac-sobie-marka/

Nawrocka, E., Niezgoda A. (2017). Współudział konsumentów w tworzeniu produktu turystycznego. Studia Oeconomica Posnaniensia, 5(4), 128-129.

PARP. (2018). Raport o stanie sektora małych i średnich przedsiębiorstw w Polsce. Warszawa: PARP. 
Pritchard, J. (2019). How to Send and Receive Money with Facebook Messenger. Retrieved from: https:// www.thebalance.com/facebook-messenger-payments-send-and-receive-money-315074

Ritzer, G., Jurgenson, N. (2010). Production, consumption, prosumption: The nature of capitalism in the age of the digital 'prosumer'. Journal of Consumer Culture, 10(1), 13-36.

Safko, L. (2010). The social media bible: tactics, tools, and strategies for business success. John Wiley \& Sons.

Stelzner, M.A. (2019). How Marketers Are Using Social Media to Grow Their Businesses. Social Media Marketing Industry Report. Social Media Examiner.

Stephen, A.T. (2016). The role of digital and social media marketing in consumer behavior. Current Opinion in Psychology, 10, 17-21.

Szewioła, P. (2019). ZUS kontroluje użytkowników Facebooka. Retrived from: https://praca.gazetaprawna.pl/artykuly/1102686,zus-kontroluje-uzytkownikow-facebooka.html

Tapscott, D., Williams A.D. (2006). Wikinomics. How Mass Collaboration Changes Everything. Portfolio. Toffler, A., Toffler, H. (2006). Revolutionary Wealth. New York: Doubleday.

Unlocking the power of brand trust. Industry insights on managing reputation and risk across the Business. (2019). Research Study, Brand Security. Retrived from: https://collateral-library-production. s3.amazonaws.com/uploads/asset_file/attachment/11949/CS11527_Research-Study-Brand_ FINAL____.pdf

We are social. (2020). Global Digital Report. Retrived from: https://wearesocial.com/global-digital-report-2020

Witczak, O. (2016). Przedsiębiorstwo jako prosument mediów i serwisów społecznościowych. Przedsiębiorczość i Zarządzanie, XVII(11/II), 293-305.

Iwona Lupa-Wójcik, $\mathrm{PhD}$ in Economics in the discipline of management sciences, assistant professor at the Institute of Law and Economics, Pedagogical University of Krakow. She has many years of experience as an entrepreneur and entrepreneurial trainer. Her research interests include social media in marketing and management, entrepreneurship, strategic marketing management, as well as cooperation economics and sharing economy.

ORCID: https://orcid.org/0000-0003-1673-7077

\section{Address:}

Uniwersytet Pedagogiczny im. Komisji Edukacji Narodowej w Krakowie

Instytut Prawa i Ekonomii

ul. Podchorążych 2

30-084 Kraków, Polska

e-mail: iwona.lupa@wp.pl 